\title{
Funksjonelle og strukturelle tilnærmingsmåter i kriminologien
}

\author{
Av magister CECILIE HØIGÅRD, Oslo
}

Begrepene om funksjon og struktur utgjør to grumnpillarer i sosiologisk teori. Derfor vil jeg bruke store deler av denne forelesningen til å utrede innholdet i disse nokså innfløkte begrepene. Det gj $\phi \mathrm{r}$ jeg med desto bedre samvittighet fordi den andre delen av oppgaven - begrepene belyst gjennom eksempler fra norsk kriminologi - er relativt fort besvart, rett og slett fordi begrepene ikke har hatt så stort nedslagsfelt her hjemme. Temaets størrelse gjør at jeg må konsentrere meg om å få fram noen hovedlinjer, for de som er interesserte i mer sofistikerte snurrepiperier har jeg utarbeidet en litteraturliste med henvisning til noen av de mer sentrale teoretiske bidragene (se nr. 1--7).

Det absolutt vanskeligste av disse to begrepene er begrepet om struktur, så jeg begynner like godt med det. Begrepet struktur har funnet sitt anvendelsesområde innenfor svært forskjellige felter. „En lærer kan f. eks. si om en avhandling at den er godt strukturert for å fremheve dens gode disposisjon. Bedriftslederen og fagforeningsmannen vil bruke ordet ,strukturert" om et foretagendes eller et markeds organisasjon. Fra og med Karl Marx nøler sosial $\varnothing$ konomene mindre og mindre med å omtale som „,infrastrukturer“ alle $\phi$ konomiske og sosiale realiteter i et bestemt land, mens arkitektene - itråd med den opprinnelige latinske betydning av structura (bygning) - mener fundamentet $o g$ armeringen av et byggverk. Lingvister og de som anvender lingvistenes metoder i de humanistiske vitenskaper (etnologi, sosiologi, historie) taler om strukturer for å betegne bestemte solidaritetsforhold, en bestemt orden mellom to eller flere trekk i et språk, i et slektskapssystem, i fortellende stil, i matskikker, i klesmoten etc.“ (4). Så forskjellige disse bruksmåtene av begrepet struktur enn er, har de likevel noe felles, fordi alle handler om den relativt stabile måten som delene $i$ i en helhet er ordnet på. Dette kan altså tjene som en almen bestemmelse av begrepet struktur - den relativt stabile måten som delene i en helhet er ordnet på innbyrdes. En strukturell tilnærmingsmåte til kriminologien kan altså i og for seg både være biologisk, psykologisk, pedagogisk, lingvistisk eller sosiologisk, så lenge man bestreber seg på å vise hvordan de ulike delene $\mathrm{i}$ en helhet peker tilbake til hverandre og gir hverandre mening. For denne oppgaven innsnevres imidlertid tilnærmingsmåten drastisk av den andre delen

1) Oppgitt tema for prøveforelesning til magistergraden i kriminologi. 
av begrepsparet - begrepet om funksjon - og derfor skal jeg holde meg til det spesifikt sosiologiske strukturbegrep. Begrepet om sosial struktur er på mange måter det sosiologiske begrep par excellence, så og si enhver sosiolog med teoretiske aspirasjoner har sin egen utledning av begrepet. Jeg skal ikke gjennomgå min trøstesløse vandring i disse definisjonene. La meg bare som et eksempel på løsheten i begrepsdefinisjoner nevne et eksempel fra en presumptivt autoritativ kilde: Encyclopedia of the Social Sciences (5). Der sier Udy at sosial struktur er ,... . det totale $m \phi$ nster av kollektive menneskelige fenomen som ikke kan forklares ved arv eller natur." I f $\varnothing$ lge denne definisjonen er sosial struktur lik alle sosiale fenomener. Jeg synes at dette er nokså intetsigende og skal velge en annen vei for å bestemme sosial struktur, denne er også mer i tråd med den måten funksjonalister tenker seg den sosiale strukturen på. Utgangspunktet her er det sosiale system som i sosiologien defineres som samhandling eller interaksjon mellom to eller flere individer. Vi har allerede ved den almene bestemmelsen av begrepet struktur kommet fram til at det handler om den relativt stabile måten delene i en helhet er ordnet på innbyrdes, eller monstret $\mathrm{i}$ ordningen av en helhet. Et sosialt systems struktur vil altså være den regelmessige måten menneskelig interaksjon er ordnet på. Sosiale system finnes på mange nivåer - fra det system et kjærestepar utgjør, til familien som sosialt system over til lokalsamfunnet og videre opp til det norske samfunn - ja, man kan selvfølgelig fange inn enda videre - over til Vest-Europa, land med en kapitalistisk produksjonsmåte osv. Det er skrevet mange og lærde bøker om muligheten av å trekke grenser for de forskjellige sosiale systemer, her hjemme har f. eks. Odd Rams $\varnothing y$ skrevet doktoravhandling om temaet (8). Jeg har selvsagt ingen mulighet for å forfølge alle disse nivåene videre og skal $i$ resten av forelesningen velge det nasjonale samfunn - Norge slik det er i dag — som eksempel på et sosial system. I samfunnet kommer de regelmessige menneskelige samhandlingsformer best til uttrykk gjennom det sosiologer kaller institusjoner, dvs. bestemte măter å handle på, bestemte normer og verdier som er knyttet til avgrensete problemområder i samfunnet - f. eks. den фkonomiske institusjonen, familieinstitusjonen, den rettslige institusjonen osv. Etter alle disse definitoriske irrganger kan vi altså bestemme et samfunns sosiale struktur på et gitt tidspunkt som

1. Det regelmessige og stabile i menneskelig samhandling slik det uttrykkes $i$

2. Samfunnets institusjoner og $\mathrm{i}$

3. Forholdet mellom disse institusjonene. 
Dette lyder antakelig svært teoretisk og abstrakt. For å få det hele litt mer håndfast, kan vi tenke oss hvordan et riss av Norges sosiale struktur $\mathbf{i}$ dag sånn noenlunde ville se ut:

familie institusjon

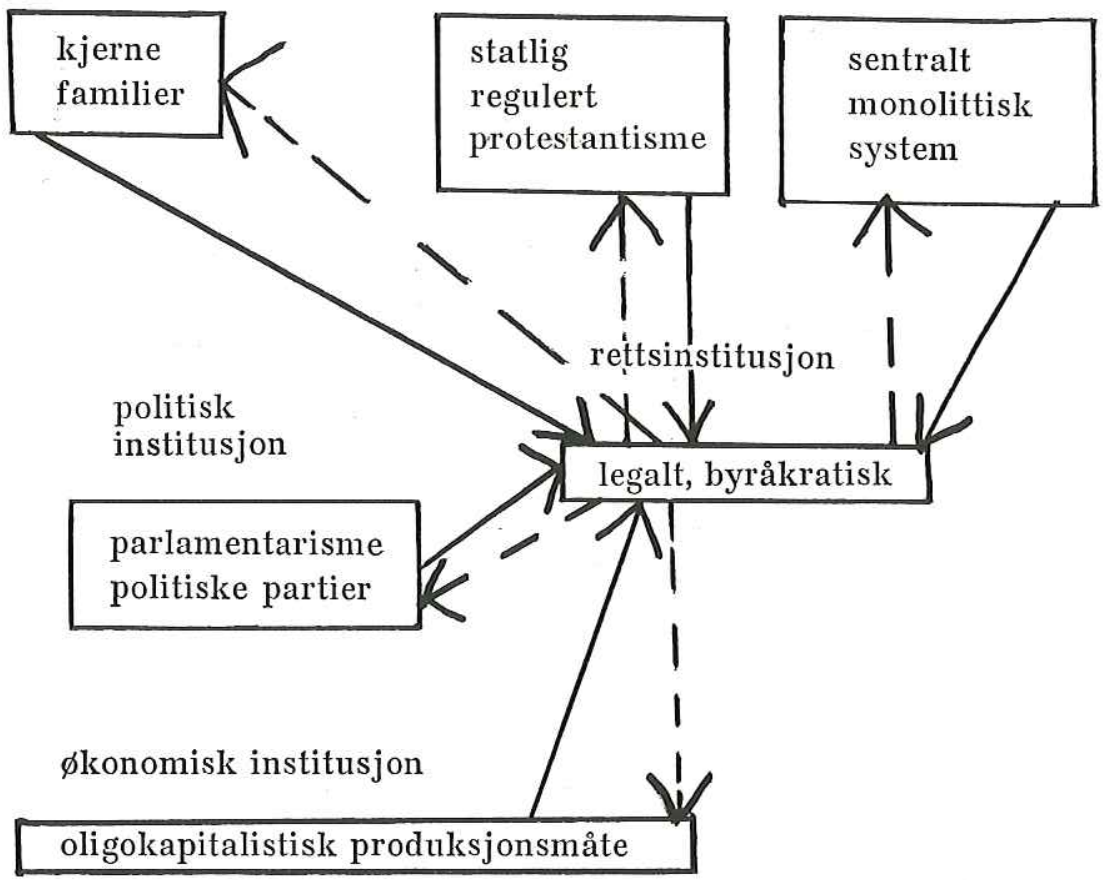

utdannings institusjon

Vår samfunnsstruktur består altså av disse institusjonene, og av forholdet mellom dem, hvordan de bestemmer hverandre, setter grenser for hverandre osv. ${ }^{1}$ ) En strukturell tilnærmingsmåte til kriminologien vil altså ut fra denne bestemmelse av struktur bestå i å se på hvordan relativt dype stabile trekk $i$ måten vi har organisert vårt sosiale liv på, innfluerer på det som skjer innen den rettslige institusjonen (de hele pilene). Jeg skal gi et par eksempler på måter dette er gjort på senere, men f $\phi$ rst skal jeg prøve å forklare hva en funksjonell tilnærmingsmåte til kriminologien består i. Og det er heldigvis atskillig lettere, fordi begrepet „funksjon“ innen sosiologien er mye mer avgrenset og bestemt enn begrepet struktur når f $\varnothing$ rst strukturbegrepet er

1) Pilene forklares siden. 
bestemt. En funksjonell tilnærmingsmåte er særlig brukt innen en retning innen amerikansk sosiologi — strukturfunksjonalismen - der Talcott Parsons og Robert Merton har vært de mest innflytelsesrike, og innen britisk sosialantropologi, særlig av Malinowski og Radcliffe-Brown. Hvordan kan et samfunn fungere, sp $\phi r$ en strukturfunksjonalist. Utgangspunktet for ham er at et samfunn utgjør et sosialt system med bestemte funksjonelle behov. Disse behovene kan være av mange slag, f. eks. behovet for stadig rekruttering til systemets roller, behovet for $\varnothing$ konomisk tilpasning, og det systembehov strukturfunksjonalisten setter i h $\phi y$ setet, behovet for integrasjon eller solidaritet mellom samfunnsmedlemmene. Strukturfunksjonalisten vil hevde at et sosialt system består av strukturer som ivaretar disse funksjonelle behovene, og at det er konsekvensene av disse strukturene som gjør strukturene forståelige (9). En funksjon er altså ikke en hvilken som helst virkning av sosiale strukturer, begrepet blir av og til brukt på denne løse måten i norsk sosiologi - men en bestemt type virkninger av sosiale strukturer. Merton (6) definerer begrepet slik i sin svære bok om sosial teori og sosial struktur: Funksjon er de observerte konsekvenser som fører til et gitt sosialt systems tilpasning. Og omvendt, dysfunksjon, som er de observerte konsekvenser som fører til et gitt systems minskende tilpasning. Et annet viktig begrepspar i strukturfunksjonell analyse er manifeste og latente funksjoner. Manifeste funksjoner er slike systemtilpassende mekanismer som folk er klar over og setter pris på, latente funksjoner er systemtilpassende mekanismer folk ikke er klar over - bortsett eventuelt fra den vise sosiolog, da. Det klassiske eksemplet her er Hopienes regndans - en dans Hopiene danser med det formålet å skaffe regn. Sosiologen derimot, utstyrt med begrepet om latent funksjon og med meteorologisk kunnskap om dansens ringe innvirkning på værsituasjonen, ser på dansen som det sosiale systems listige nyttiggjørelse av Hopienes aktivitet for sine egne sosiale behov, over hodet på de bevisst handlende individer; denne sosiologen ser at dansens latente funksjon er å skape samhold eller integrasjon i Hopisamfunnet ved at de samles om en felles hyggelig aktivitet som dansen da forutsettes å være.

Det er altså bare de virkninger som har implikasjoner for opprettholdelsen av samfunnets institusjoner og forholdet mellom dem som er relevante i en funksjonell analyse av samfunnet. En strukturfunksjonalist opererer med en middel - mål tankegang gang på systemnivå. Midlet er sosiale strukturer - målet er funksjoner, dvs. konsekvenser som bidrar til at systemet opprettholdes. Dette tankeskjemaet f $\phi r$ rer lett til at man via en analogi fra biologien betrakter samfunnet i lys av en likevekt - eller ekvilibriumsmodell. Denne analogien tar utgangspunkt 
i en bok av Cannon, „The Wisdom of the Body“ (11), der han viser hvordan fysiologiske prosesser bidrar til å oppretholde en optimal balansetilstand i menneskekroppen. Man tenker seg da at samfunnet kan sammenliknes med en slik menneskekropp; hver gang ytre eller indre krefter truer med å forstyrre samfunnets likevekt, trer funksjonelle mekanismer i virksomhet og f $\phi$ rer samfunnet tilbake til dets optimale leie. Integrasjonen i samfunnet er altså termostatstyrt, synker integrasjonen under et visst nivå, slås mekanismene på til normalstillingen igjen har inntrådt og mekanismene kan så hvile seg litt før de igjen må til for å kompensere en ny underskuddsbalanse.

Svakhetene ved denne modellen er åpenbare, og det er da også reist en storm av kritikk mot strukturfunksjonalismen. Her skal jeg bare ta for meg et avgjørende svakt punkt i modellen, fordi denne svakheten også går igjen i de forholdsvis få norske kriminologiske arbeider som er påvirket av denne teoretiske tradisjonen innen sosiologien. Det er vel antakelig nokså greitt å avgjøre hva som er syke eller sunne tilstander i den menneskelige organisme. Men hvordan ser det sunne samfunn ut? Hva vil et samfunns optimale leie si? På grunn av manglende kriterier og vaghet på dette punktet blir denne optimale tilstanden ofte implisitt i strukturfunksjonalismen identisk med status quo. Bevarelsen av samfunnssystemet blir et gode i seg selv, og strukturer betrakites som hensiktsmessige fordi de bidrar til et systems opprettholdelse. Merton, som har utarbeidet et detaljert paradigma for funksjonell analyse, bruker mye energi og mange sider på å tilbakevise påstanden om at strukturfunksjonell analyse n $\varnothing$ dvendigvis må bli konservativ. Han viser at samfunnsfilosofien til de britiske sosialantropologene - filosofien om at ethvert samfunn er perfekt integrert, at alle elementer i samfunnet er funksjonelle og viktige, og at samfunnet er statisk - ikke er innbakte forutsetninger for bruken av en funksjonell metode. Men enda han er ekstra på vakt mot denslags misbruk av metoden, faller han selv gang på gang $\mathrm{i}$ den samme grav. Som et eksempel på fruktbar bruk av den strukturfunksjonelle metoden, ubefengt av konservativ ideologi, bruker han eksemplet den politiske maskin. Hovedpoenget her er at de korrupte lokale politiske partier i USA oppfyller viktige latente funksjoner i lokalsamf unnet, f. eks. ved å beskytte den lokale illegale omsetning av alkohol og narkotika, beskytte ulovlige spillebuler, og s $\phi \mathrm{rge}$ for mobilitetsmuligheter for folk som ellers i det amerikanske samf unnet ville være avskåret fra yrkesmessig avansement.

Som en konklusjon på unders $\varnothing$ kelsen av den politiske maskin sier Merton meget bombastisk at: „Ethvert fors $\varnothing$ k på å eliminere en eksisterende sosial struktur - (her den politiske maskin) uten å s $\phi$ rge for adekvate alternative strukturer for å fylle de 
funksjoner den bannlyste struktur fyller, er dømt til fiasko". (6) I følge David Matza tjente den politiske maskinen f $\varnothing \mathrm{rst}$ og fremst til å utnytte fattige etniske minoritetsgrupper, de hadde altså ikke noen særlig interesse i at maskinen skulle bestå. Dette er et typisk og motbydelig trekk ved strukturfunksjonell tankegang, man opererer ikke med ulike konsekvenser av sosiale strukturer for ulike sosiale klasser, men tilslører konfliktene under generelle utsagn om det sosiale systems tilpasning. Jeg er opptatt av dette Merton-sitatet om at ethvert fors $\phi \mathrm{k}$ må mislykkes, fordi Merton taes til inntekt for at tesen om funksjonalismens konservatisme er motbevist en gang for alle i nyere tidsskriftsartikler av samfunnsvitere som vil bringe strukturfunksjonalismen til heder og verdighet igjen (se f. eks. 12, 13, 14, 15). Uansett hvordan det var med den politiske maskin, har påstanden om n $\varnothing$ dvendigheten av funksjonelle ekvivalenter store konsekvenser, fordi det impliserer et samfunnssyn der samfunnet ikke oppfattes som noe historisk skapt av menneskelig virksomhet, men som et sosialt system styrt av evige og naturlige systembehov. La meg belyse konsekvensene av et slikt samfunnssyn med et eksempel. En privatkapitalistisk produksjonsmåte krever en arbeidets reservearme for å være stabil. Undertrykkelsen av kvinner tjener funksjonen å være en slik reservearme. I f $\varnothing$ lge Merton er det da umulig å oppheve kvinnens undertrykking $f \varnothing r$ vi har en funksjonell ekvivalent til den kvinnelige reservearmeen, og den politiske kampen vil bestå i å skape en annen undertrykt reservearme, f. eks. s $\phi$ rge for bedre og billigere imporit av fremmedarbeidere. Skjevheten i denne tankegangen tror jeg skyldes at man i strukturfunksjonell analyse tar som utgangspunkt et systemt sosiale behov, mens man ikke sp $\phi \mathrm{r}$ om hva disse behovene bunner i - hvilke sosiale strukturer som genererer disse behovene - de bare er der. Derfor kan man heller ikke ta stilling til behovenes legitimitet, og eventuelt bekjempe de sosiale strukturer som skaper dem, i vårt tilfelle bekjempe en privatkapitalistisk produksjonsmåte for å bekjempe kvinnens undertrykkelse, fremfor å sørge for at nye grupper av folk blir undertrykt. Analysen starter så og si en runde for sent til å bli meningsfull. La meg illustrere dette poenget med en liten skisse:

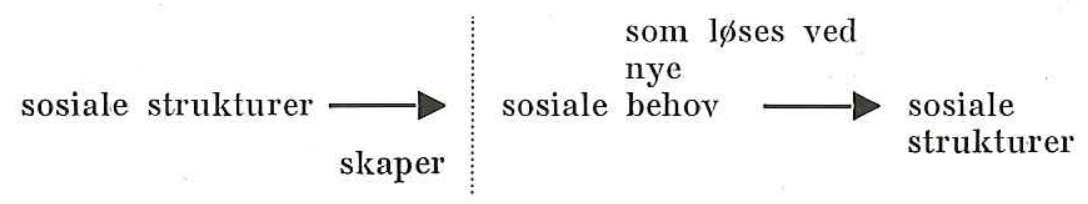

Strukturfunksjonell analyse starter f $\phi$ rst etter den prikkete linja.

Når Merton som er så på vakt mot ideologiske elementer i strukturfunksjonell analyse, selv blir et offer for dem, er det 
ikke urimelig å anta at strukturfunksjonalismen mangler viktige begreper for samfunnsforståelsen. Et begrep som motsetninger, f. eks. har ingen plass i funksjonelle analyser. Riktignok opererer Merton i sitt paradigma med begrepet dysfunksjon, men begrepet er aldri kommet ut av lærebokas st $\phi$ vete sider, -- jeg har aldri st $\varnothing \mathrm{tt}$ på en strukturdysfunksjonell analyse i sosiologisk litteratur. Begrepsapparatet i strukturfunksjonalismen gjør at man lett bare plukker ut visse trekk i den sosiale virkelighet, mens man totalt overser andre og mye viktigere trekk som peker fremover mot sosial endring.

Betyr dette at vi skal forkaste strukturfunksjonelle tilnærmingsmåter til kriminologien? Svaret er mest ja, men litt nei. Ja fordi det bærer galt av sted dersom vi n $\varnothing$ yer oss med strukturfunksjonalismens begreper og metoder. Nei fordi kunnskap om metoden kan være fruktbar såsant den kombineres med bruk av andre begreper. Jeg benytter anledningen til å drive litt selvreklame. I et kapittel i avhandlingen min har jeg prøvd å vise noen sammenhenger mellom strukturfunksjonalismen og dialektisk materialisme (16). Hovedpoenget er at kunnskap om funksjonell metode kan være fruktbar fordi den utarbeider mye mer i detalj trekk ved samfunnslivet som bare antydes i dialektisk materialisme, samtidig som bruk av begrepene i dialektisk metode hindrer at vi faller i strukturfunksjonalismens ideologiske fallgrav. Metoden, som altså pr $\varnothing v e r$ å forklare sosiale strukturer ved å unders $\phi$ ke hvilke konsekvenser de har for samfunnets stabilitet tatt som en helhet, er god. Ideologien derimot, som tegner et vakkert, men falskt bilde av samfunnet - det Gode Samfunn, der alle er integrerte, alle har de samme grunnleggende verdier og alle vil bevare Fedrelandet i dets nåværende hyggelige form, fører på avveie.

Dette ble mye abstrakt sosiologisk teori. Jeg skal gå over til å se på konkrete anvendelser av tilnærmingsmåten om et фyeblikk, la meg bare si litt om forholdet mellom dem. En strukturell tilnærmingsmåte slik jeg har beskrevet den vil altså bestå i å vise hvordan relativt dype, stabile trekk i måten vi har organisert vårt sosiale liv pá bestemmer hva som skjer innen den rettslige institusjonen, f. eks. hvordan vårt $\phi$ konomiske system kan produsere avvikere - eller kriminelle. En unders $\phi$ kelse av hvordan strukturrasjonalisering kan skape arbeidsl $\phi$ shet - n $\varnothing \mathrm{d}$ - og eventuelt vinningskriminalitet vil være en typisk strukturell tilnærmingsmåte til kriminologien. En funksjonell tilnærmingsmåte, derimot, setter seg så og si den omvendte målsettingen og unders $\varnothing$ ker på hvilken måte det som skjer innen rettsinstitusjonen slår tilbake på den sosiale struktur og stabiliserer den (prikkete piler, fig. 1). Som et enkelt og lite raffinert eksempel kan vi f. eks. tenke oss at fengsling av opposisjonelle poli- 
tiske ledere i et samfunn truet av indre oppløsning kan passifisere massene og bidra til at samfunnet ruller videre som det er, uten at den grunnleggende sosiale struktur фdelegges. En strukturell tilnærmingsmåte n $\phi$ dvendiggj $\phi r$ altså ingen funksjonell analyse - man kan se på hvordan de ulike institusjonene og forholdet mellom dem skaper avvik, og samtidig gi d $\phi y t e n ~ i$ hvordan dette virker tilbake på denne sosiale strukturen. Men en funksjonell tilnærmingsmåte derimot, impliserer i det minste i prinsippet en strukturell analyse - poenget er jo nettopp å se hvordan en delstruktur (f. eks. rettsinstitusjonen) innvirker på, styrker eller svekker, resten av den sosiale struktur. Altså, en strukturell tilnærmingsmåte impliserer ingen funksjonell tilnærmingsmåte, en funksjonell tilnærmingsmåte impliserer en strukturell tilnærmingsmàte.

Jeg nevnte innledningsvis at disse to tilnærmingsmåtene slik jeg har definert dem ikke har vært særlig fremtredende i norsk kriminologi. La meg derfor bare ganske kort henvise til to utenlandske arbeider hvor metodene er svært rendyrkete og lettere å få tak på. Det beste eksempel på en samfunnsstrukturell tilnærmingsmåte er - nær sagt selvfølgelig - den franske sosiologens Emile Durkheims store verk fra 1897 om selvmordet (17). Hovedpoenget hans meget grovt er at $\phi$ kningen i selvmord i Frankrike på den tida han skrev arbeidet, skyldes forholdet mellom to faktorer, for det f $\phi$ rste den store grad av arbeidsdeling i det franske samfunn, for det andre at den fjernheten dette kan skape mellom mennesker ikke var kompensert for i form av utbygging av sekundærgrupper som kunne binde folk sammen igjen. Boka har en strukturell tilnærmingsmåte fordi den prøver å forklare den høye selvmordsralen med stabile trekk i det franske samfunn, trekk som var felles for alle franskmenn. Dette siste poenget - at avvik forklares ved trekk som er felles for medlemmene $\mathrm{i}$ et samfunn - er en interessant og viktig kontrast til den måten kriminalsosiologi ofte drives på. Her forklares avvik ofte ved de patologiske eller atypiske variasjoner av menneskelig samhandling, f. eks. ved oppløste ekteskap, taping på skolen, i yrkeslivet osv., altså ikke ved felles trekk som alle samfunnsmedlemmene er underkastet, men ved hendelser som bare rammer de få og uheldige - sat på spissen, da. Durkheim derimot, bruker altså avvik som en slags seismograf for dype fellestrekk i samfunnet, og boka munner ut i - ikke en strategi for å minske selvmordsraten i og for seg - men i en strategi for å endre det mye mer alvorlige fenomen: den manglende solidaritet i det franske samfunnet. Den andre boka jeg vil nevne som prototypen på en funksjonell tilnærmingsmåte er Eriksons bok om Puritanersamfunnet i Massachussett Bay (18). Dere kan jo ha innvendingene mot strukturfunksjonalismen i bakhodet 
når dere leser den, og eventuelt la det være litt malurt i den begeistringens rus man lett settes i av Eriksons uhyre elegante og velskrevne bok.

Også tilslutt da, noe om tilnærmingsmåtene og norsk kriminologi. Jeg har spekulert på hvorfor de ikke er mer anvendt i norsk kriminologi. En begrunnelse er helt åpenbar, begrepene er spesifikt sosiologiske begrep, og kriminologi bedrevet av sosiologer har vi her i Norge bare hatt de siste femten åra. Av de seks arbeidene jeg skal si noen ord om, er tre av Christie og tre av Aubert, som riktignok er utdannet jurist, men som nå innehar et professorat i generell sosiologi. En annen ting er kanskje at norsk kriminologi har vært mer opptatt av det Merton kaller ,theories of the middle range“ - teorier med middels gyldighetsområde - som en slags mellomting mellom meget spesifiserte hypoteser med liten grad av generalitet og de store totale teoriene. Det er vel nokså rimelig at nye vitenskaper begynner i den letteste enden - og det er helt sikkert ikke de totale teoriene. Slike teorier vil kanskje ikke oppstå f $\varnothing \mathbf{r}$ feltet er sånn noenlunde mettet med „middels“ teorier. En tredje grunn som man selvf $\varnothing$ lgelig ikke kan se bort fra, er kanskje at norske kriminologer rett og slett ikke synes at disse tilnærmingsmåtene er særlig gode.

Men i det minste i et norsk arbeid er heldigvis en strukturell tilnærmingsmåte helt tydelig, nemlig Christies arbeid om Vold i Norge (19). Dette arbeidet er på mange måter en interessant parallell til Durkheims arbeid om selvmord, tankegangen likner på avgjørende punkter. Christie viser ved tallenes tale at Norge har en usedvanlig posisjon som et ikke-voldelig land, hva voldskriminalitet angår. Han sier at ,voldsnivået $i$ et land har sammenheng med samfunnsforholdene for $\phi$ vrig“ og forklarer Norges lave voldsnivå med tre trekk ved det norske samfunn. For det f $\phi$ rste har vi fått en endret referanseramme for lidelse. Med bedre levevilkår tåler vi mindre av fysisk lidelse. For det andre har vi andre løsningsalternativer enn voldsut $\phi$ velse ved konflikter. Den italienske vendetta kan være motstykket her. For det tredje skyldes det lave voldsnivået differensieringsnivået $\mathrm{i}$ det norske samfunn. Dette siste punktet er det mest interessante etter mit skjønn, og jeg har lyst til å koste på meg forn $\varnothing y e l s e n$ av å sitere Christies beskrivelse av dette:

„Det er store nok indre forskjeller i det norske samfunnet til at vi har konfliktløsere. Men det er ikke større enn at vi alle befinner oss innen et fellesskap $i$ verdier og at vi vet at vi befinner os innen dette fellesskap. Vi har felles forfedre, felles historie, fellesskap i livsstil. Vi har selvfølgelig klasseforskjeller, men ogsá store områder hvor klasse ikke spiller noen rolle. Vi er innfluert av en puritansk livsstil, akter arbeid mer enn fritid, alvor mer enn sp $\phi \mathrm{k}$ og har kanalisert 
mye av vårt rituelle liv over i hyppige og anstrengende møter med hav og ski og fjell - stadig det norske alternativ til kjemiske reiser. Vi påstås å tilhøre en pluralistisk kultur, men dens monolittiske særpreg er vel egentlig dominerende. Det ene sentralt styrte skolesystem, det ene kringkastingssystem, det ene helt dominerende kirkesamfunn, den ene landsorganisasjon, den ene arbeidsgiverorganisasjon; egentlig ligner vi hverandre til forveksling, til kjedsommelighet, - og til beskyttelse av liv, legeme og helbred" (19).

Dette må da være prototypen på en strukturell tilnærmingsmåte! Som Durkheim forklarer Christie her avvik med stabile trekk i måten vi lever vårt sosiale liv på, mer eller mindre felles for oss alle. Som Durkheim bruker Christie avvik som et speil for samfunnet; han bruker Norges lave voldsnivå til å fortelle oss noe viktig om det norske samfunn. Og som hos Durkheim munner arbeidet ut i brede, generelle samfunnsreformerende forslag. Christie har selv sagt at „Vold i Norge“ ikke er noe interessant arbeid, teoretisk sett. Utfra det foregående er jeg dypt uenig med ham i dette, og jeg ser intet poeng i å skjule min begeistring for arbeider hvor poenget ikke er det tradisjonelt kriminologiske - at kunnskap om det norske samfunn er interessant fordi det kaster lys over kriminologien — men hvor poenget tvert om er det motsatte - kriminologien er interessant fordi den kan gi oss kunnskap om det norske samfunn.

To arbeider til kan føres opp på ,struktur"-siden. I „Langhåret livsstil“ (20) prøver Christie å vise hvordan denne livsstilen så og si er en reaksjon på og et vrengebilde av den tradisjonelle livsstil i det mette, søvnige norske samfunn. En idealtypisk beskrivelse av den langhårete vil inneholde elementer som antikonsument, tilbaketrekker, $\phi$ yeblikksorientert og en indreorientert livsorientering. Det tredje strukturelle arbeidet er Auberts om Straff og Lagdeling (21). La meg bare kort minne om hovedpoenget som er at samfunnets lagdeling avspeiles i en tvedeling i rettsvesenets klientell og praksis. Den ene delen - som sjelden blir frifunnet og som id $\varnothing$ mmes de hardeste straffarter, består av personer som er meget løst hektet til det nett av gjensidige avhengighetsforhold samfunnet består av, de har lфs tilknytning til arbeidslivet, de er ofte ugifte, og mangel på bopel umuliggj $\phi \mathbf{r}$ varige naboskapsbånd. Den andre kategorien av lovovertredere hører hjemme i det store nett av gjensidige sosiale avhengighetsforhold i samfunnet, og det er nettopp medlemsskapet i dette nettet som er utgangspunktet for lovbruddet, lovovertrederen begår her sitt lovbrudd $i$ kraft av kasserer, skattesnyter, bilist, arbeidsgiver osv. Flere arbeider enn disse tre tror jeg ikke hører hjemme her, hvis ikke begrepet om en samfunnsstrukturell tilnærmingsmåte presses un $\varnothing$ dig hardt.

På ,funksjons"-siden har jeg lett fram tre arbeider, et av 
Christie om "Sort og Hvitt" (22) og to av Aubert, „En lov i s $\varnothing$ kelyset" (23) og „Om straffens sosiale funksjon“ (24). Grunnen til at jeg har klassifisert "Sort og Hvitt" under funksjonelle tilnærmingsmåter er den første siden i arbeidet, der Christie har lagt fram en del betraktninger om forbryteren som en sosialt nyttig person. Den sosiale nytten begrunnes med f $\varnothing$ lgende tre forhold: For det første forbryteren som en slags omvendt etikkens ivaretaker: „Forbryteren driver opplysningsarbeid om hva som er riktig ved å gjøre det gale“. For det andre, ,lovbryterens løsning er slik at vi andre lett kan forenes i en felles avstandstagen, og det i en tidsalder hvor uenighet om svært mange grunnleggende verdier er forsvunnet", som Christie uttrykker det. For det tredje er lovbryteren nyttig som aggressjonsmottaker. Deler av artikkelen om "Sort og Hvitt" danner innledningen til kriminalsosiologien (25), og synspunktene har, på tross av det ringe utslag i antall sider, vært en viktig del av den felles norske kriminologiske kultur.

„En lov i søkelysel“" er en analyse av loven om hushjelpers arbeidsforhold. Da den danner noe av grunnlaget for betraktningene i „Om straffens sosiale funksjon“, skal jeg holde meg til denne boka. Aubert argumenterer her grundig og godt for at straffens funksjoner er andre og viktigere enn de manifeste funksjoner vi stort sett tilskriver straffen: straffens individualpreventive og almenpreventive virkninger. Skal vi forstå strafferetten, sier Aubert, må vi se etter straffens latente funksjoner, - stabiliserende virkninger av straffen som i liten grad er forutsett eller godtatt i de offisielle programerklæringene. Som et eksempel på hva slags virkninger Aubert tenker på kan vi se på lover som myter om virkeligheten.

Av og til ser man en nesten magisk overbevisning om at et sosialt problem er l $\phi$ st i og med at en bestemt ordning av forholdene er fastlagt i lovs form - håndhevningen av loven derimot er ikke så viktig. For mange vil det avgjørende være om retten har godtatt deres eget syn, deres egne normer og verdier. Et eksempel på en slik lov som har den stabiliserende latente funksjon å skape sosial og politisk fred, er Hushjelploven av 1948. Den var et uttrykk for et generelt humanitetskrav innen enkelte grupper. Disse krava slo f $\varnothing$ rst gjennom i lovgivningen på et tidspunkt da hushjelpenes kår av andre grunner var blitt tålelig bra. Loven representerte på visse punkter ikke mer enn en stadfesting av status quo, og det ble ikke gjort fors $\phi k$ på å håndheve den på de punkter hvor den gikk utover status quo. Likevel, sier Aubert, fyllte loven en funksjon for alle dem som var urolige på grunn av hushjelpenes kår. Nå sto det $\mathrm{i}$ loven at de skulle ha gode og rimelige arbeidsbetingelser. Bryter husmora loven, blir hun til og med truet med straff. Det kan ha gitt 
de interesserte kretser som sto bak loven, en følelse av at deres rettferdskrav ble imøtekommet med virkelig alvor, og dette har betydning for et stabilt sosialt og politisk klima.

Men hva med den tredje part i dette spillet - hushjelpene? Har loven noen funksjon for dem? Og de kriminelle - hvilke fordeler har de av å være helgenens motspiller i det sosiale system? Dette drøftes ikke i disse arbeider, jeg i hvertfall blir sittende igjen med en beklemmende f $\emptyset$ lelse av at de er uunngåelige ofre på Samfunnsintegrasjonens Hellige Alter. Nå skal det riktignok sies at verken Aubert eller Christie er blitt oppfattet slik i den praktisk-kriminalpolitiske debatt, fordi de der klart har valgt småkårsfolks side. Auberts bok om straffens sosiale funksjon dannet f. eks. utgangspunktet for en diskusjon av det urettferdige i å putte mennesker i fengsel i ly av begrepet om almenprevensjon for å oppnå helt andre ting. Også andre deler av både Christies og Auberts forfatterskap gjør det svært urimelig å ta dem til inntekt for at påføring av menneskelig lidelse rettferdiggjøres av hensynet til det felles beste. Mitt poeng er bare at $\mathrm{i}$ de arbeider hvor en funksjonell tilnærmingsmåte benyttes, forsvinner dette perspektivet så og si helt, og teksten ligger åpen for den slags urimelige mistolkninger. Dette er i grunnen ikke så rart, fordi strukturfunksjonalismen slik jeg har pr $\emptyset \mathrm{vd}$ å vise, mangler begreper til å dekke dette perspektivet, og de begrepene strukturfunksjonalismen har, styrer interessefeltet nettopp over i slike urimeligheter.

En mer fundamental mangel i disse funksjonsarbeidene er etter mitt skjønn at selve integrasjonsbehovet fremstår som uproblematisk og selvfølgelig i dem. La meg bare kort til slutt i påstands form antyde hva jeg tenker på med dette. I et samfunn som vårt, der den ene klassen lever av å utbytte og undertrykke den andre klassen vil samhold eller integrasjon på tvers av klassegrensene være en falsk integrasjon. Med dette mener jeg at betingelsene for ekte integrasjon, sammenfallende interesser i det store og hele - ikke er til stede, tvert om, det som tjener den ene klassens interesser, er som regel i strid med den andre klassens interesser. Å betrakte den integrerende effekt utgruppene har på et samfunn som en slags servicefunksjon de yter - riktignok ufrivillig og riktignok dypt urettferdig - men en servicefunksjon de yter for alle oss andre, for det sosiale system eller hva man velger å kalle det, fører galt av sted, fordi bare den ene klassen har bruk for den stabiliseringseffekt integrasjonen gir. Arbeiderklassen derimot, har tvert om interesse av å oppheve og overskride det sosiale system Norge er i dag. En falsk integrasjon rundt såkalte felles interesser bidrar bare til at arbeiderklassen har vanskeligere for å bli seg dette bevisst og hemmer arbeidet for en kvalitativ samfunnsendring. 
Som en slags konklusjon eller vurdering av utfallet av disse tilnærmingsmåtene $\mathrm{i}$ norsk kriminologi vil jeg altså hevde at $\mathrm{i}$ de relativt få arbeidene hvor en funksjonsanalyse er foretatt, er utfallet i stil med de utenlandske funksjonelle arbeidene blitt tildels nokså misvisende som samfunnsbeskrivelse. Jeg foretrekker en begrepsl $\phi s$ kriminologi fremfor en kriminologi der begrepsapparatet $\mathrm{i}$ det vesentlige er hentet fra strukturfunksjonalismen. 'Til gjengjeld, og desto hyggeligere, setter jeg utslagene av en strukturell tilnærmingsmåte svært høyt, jeg synes at de har lært meg vesentlige ting om det norske samfunnet. Som et slags $\phi$ nskemål for kriminologien, da, burde vi ikke kaste bort mere tid på tradisjonell strukturfunksjonell analyse, men heller bruke kreftene — og forskningspengene - til å bygge ut det riktignok noe spede, men gode grunnlaget som er lagt for strukturelle unders $\phi$ kelser av rettsinstitusjonen.

\section{Cecilie Hфigård.}

\section{LIT'TERATURHENVISNINGER}

1) Richter, Maurice N. jr.: Social Functions and Sociological Explanation. Sociology and Social Research, 1965, 50, pp. 72-77.

2) Levy, Marion J., Jr.: Structural-Functional Analysis. International Encyclopedia of the Social Sciences, The Macmillan Company \& The Free Press, 1968, 6, pp. 21-28.

3) Cancian, Francesca M.: Varieties of Functional Analysis. International Encyclopedia of the Social Sciences, 6, pp. 29-41.

4) Leach, Edmund R.: The History of the Concept. International Encyclopedia of the Social Sciences, 1/4, pp. 482-488.

5) Udy, Stanly H., Jr.: Social Structural Analysis. International Encyclopedia of the Social Sciences, 14, pp. 489-494.

6) Merton, Robert K.: Social Theory and Social Structure. The Free Press of Glencoe, 1957, p. 645.

7) Johnson, Harry M.: Sociology: A Systematic Introduction. Routledge \& Kegan Paul Ltd. London, 1964, p. 689.

8) Odd Rams $\varnothing y$ : Social Groups as System and Subsystems, Oslo 1962, $204 \mathrm{~s}$.

9) Inkeles, Alex: What Is Sociology. Englewood Cliffs 1964, $120 \mathrm{~s}$.

11) Cannon, Walter B.: The Wisdom of the Body. N. Y. 1932, $312 \mathrm{~s}$.

12) Cancian, Francesca: Functional Analysis of Change. American Sociological Review, 1960, 25, pp. 818-827.

13) Mills, Theodore M.: Equilibrium and the Process of Deviance and Control. American Sociological Review, 1959, 24, pp. 671-679.

14) Cole, Robert: Structural-Functional Theory, the Dialectic, and Social Change. The Sociological Quarterly, Winter 1966, 7, pp. $39-58$. 
15) Sklair, Leslio: Functionalism and Deviance. London 1971, p. 26.

16) Høigård, Cecilie: Norsk kriminologi — ideologi og idyll. (Kommer). $121 \mathrm{~s}$.

17) Durkheim, Émile: Suicide. A Study in Sociology. Routledge \& Kegan Paul Ltd., London 1968, 404 s.

18) Erikson, Kai T.: Wayward Puritans. A Study in the Sociology of Deviance. John Wiley \& Sons, Inc., New York-London-Sydney, 1966, $228 \mathrm{~s}$.

19) Christie, Nils: Vold i Norge. Stensil, Oslo 1970, $35 \mathrm{s.}$

20) Christie, Nils: Langhåret livsstil. Christian Ejlers Forlag, København 1968, $28 \mathrm{~s}$.

21) Aubert, Vilhelm: Straff og lagdeling. Universitetsforlaget, Oslo $1963,149 \mathrm{~s}$.

22) Christie, Nils: Sort og hvidt. Mental Hygiejne, nr. 3—4, 1961, s. $81-86$.

23) Aubert, Vilhelm, Torstein Eckhoff og Knut Sveri: En lov i s $\varnothing$ kelyset. Sosialpsykologisk unders $\phi$ kelse av den norske hushjelplov. Akademisk forlag, Oslo 1952, 239 s.

24) Aubert, Vilhelm: Om straffens sosiale funksjon. Universitetsforlaget, Oslo 1954, $241 \mathrm{~s}$.

25) Christie, Nils: Kriminalsosiologi. Universitetsforlaget, Oslo 1965, $184 \mathrm{~s}$. 